\title{
Infection prevention and control measures for COVID-19 among medical staff in Nineveh Governorate, Iraq
}

\author{
Zakria A Kassim', SharefW Al-Mulaabed²*, Saif W Younis ${ }^{3}$, Ali A Abutiheen ${ }^{4}$
}

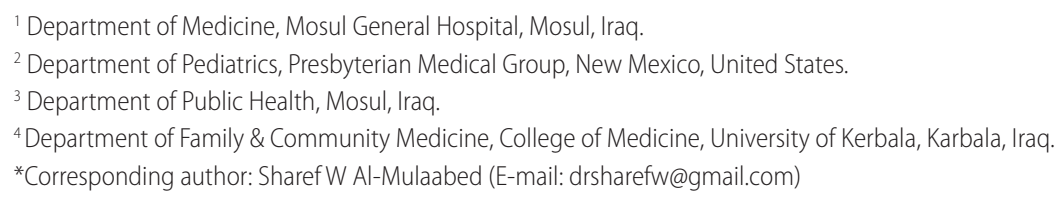

\begin{abstract}
:
Objectives: To assess the adherence to infection prevention and control (IPC) measures among medical staff working in Nineveh governorate during COVID-19 pandemic.

Methods: A cross-sectional study, using an online survey sent to different medical staff in Nineveh. The questionnaire was composed of two parts, the first included demographic information, and the second covered IPC measures. Survey was completed by medical staff witnessed COVID-19 pandemic in Nineveh governorate.

Results: The total sample was 412, of whom, 316 (77\%) were males and 142 (35\%) were physicians. Overall, the percentage of staff following different IPC measures was ranging from $31 \%$ in wearing head cover, to $97 \%$ in keeping clean hands constantly. Main missed points were found in respiratory hygiene, physical distancing, and self-isolation. Females were more likely to apply bandages to wounds and wearing gloves before examining patients. Compared to other medical staff, physicians were less compliant to washing hands, putting waste in designated places, and wearing protective cloths. Those who work in hospitals were better compliant with sterilizing hands before entering home.

Conclusion: The adherence to IPC measures was ranging from less than one-half in wearing sterile head cover, to nearly all respondents in keeping clean hands. There is a great need to provide support as well as training in regards to IPC in Nineveh governorate city.

Keywords: Infection prevention and control, COVID-19, Nineveh, Mosul, Iraq.
\end{abstract}

\section{Introduction}

Coronavirus disease of 2019 (COVID-19) is caused by severe acute respiratory syndrome coronavirus 2 (SARS-CoV-2). The outbreak was first identified in Wuhan, Hubei, China, in December 2019, and was recognized as a pandemic by the World Health Organization (WHO) on 11 March 2020. Iraq reported its first confirmed cases on 24 February 2020, while the first case appeared in Nineveh was on 22 March 2020. Nineveh is Iraq's third largest and second most populated governorate, with its capital named Mosul city. In Iraq, until 3 July 2020, the number of cases had reached 53,708 , with 2,160 deaths, and 27,912 recoveries. ${ }^{1-3}$

During the conflict between the so-called Islamic State in Iraq and Syria (ISIS) group and the Iraqi forces, 9 out of 13 public hospitals were damaged in Nineveh, slashing healthcare capacity and the number of hospital beds by 70 percent. The reconstruction of health facilities has been extremely slow and there are still less than 1,000 hospital beds for a population of more than 3.5 million people. This is half of the internationally recognized minimum standard for health service delivery in a humanitarian context. ${ }^{4}$

Looking ahead, the fear is that the pandemic will exacerbate growing inequality in Nineveh society "Without a doubt, the economic impact of COVID-19 will plunge the most vulnerable families in Nineveh deeper into poverty," therefore, special attention should be paid on infection prevention and control (IPC) measures and people awareness of its importance. ${ }^{5}$

IPC refers to policies and procedures used to minimize the risk of spreading infections, particularly in health facilities.
The purposes of IPC are to protect ourselves, our patients, and our family and community. ${ }^{6-7}$

According to current evidence, the main routes of COVID-19 virus transmission are through respiratory droplets and contact. ${ }^{8-13}$ Hence, in order to prevent and control infection, the Centers for Disease Control and Prevention (CDC) recommend the following: ${ }^{[14]}$

1. Hand washing: Hand washing is recommended to prevent the spread of the disease. The CDC recommends that people wash hands often with soap and water for at least $20 \mathrm{~s}$. It further recommended using an alcohol-based hand sanitizer with at least $60 \%$ alcohol. ${ }^{15}$

2. Respiratory hygiene: Health organizations recommended that people cover their mouth and nose with a bent elbow or a tissue when coughing or sneezing (the tissue should then be disposed of immediately). ${ }^{16}$

3. Physical distancing: (also commonly referred to as social distancing). Methods include quarantines; travel restrictions; and the closing of schools, workplaces, stadiums, theatres, or shopping centers. ${ }^{17}$

In Iraq, limited previous studies to document compliance of Iraqi medical staff in general, and those in Nineveh governorate in particular, with regards to IPC measure to any of the infectious diseases. It is speculated that due to shortage of time, lack of resources, and reduced number of staff/patients ratio, there is lack of compliance to such important measures. Moreover, despite the fact that number of COVID-19 cases are not too many in Mosul city due to city lockdown and other measures, asymptomatic infections have been well-documented as well as the fact that incubation period is thought to 
be within 14 days following exposure. ${ }^{9,18}$ Hence, IPC measures should be taken into consideration with all patients as much as possible. This study aims to assess the attitude and adherence to IPC measures among medical staff working in Nineveh governorate during COVID-19 pandemic.

\section{Materials and Methods}

A cross-sectional study conducted at Nineveh Governorate, in which there are about 3,500,000 inhabitants. Using computer application called Google forms, the survey was sent online via (Facebook messenger application) directed to members of different Facebook groups of medical staff in Nineveh. All those witnessed COVID-19 pandemics in Nineveh were invited to participate in the study. Data collection was done during 1-week period from 6 April 2020 to 13 April 2020.

The survey was especially designed to provide information on the infection prevention and control for COVID-19 after thorough review of the literatures. ${ }^{6,7,14-17,19}$ The questionnaire was anonymous and composed of two parts: the first covered demographic information of participants including gender, age, marital status, and educational level, site of work, and medical specialty. The second part represented the specific IPC questions consisting of 14 questions on general IPC measures, attitude about the most infected areas to work within, any suffering from lack of personal protective equipment, source of COVID-19 obtaining information, and finally if the responders gain benefit from the information of survey. For the IPC questionnaire, answer options were given according to 4 -point Likert-type scale ( $1=$ strongly agree, $2=$ agree, $3=$ disagree, and $4=$ strongly disagree). For the purpose of data analysis, answers " 1 " and " 2 " were grouped as a positive answer (Yes) and expressed in tables, while responses " 3 " and " 4 " were considered as (No) and analyzed accordingly.

Ethical approval was obtained from Nineveh health directorate. The questionnaire was anonymous and did not include any data on other personal identifiers. Furthermore, the participation was voluntary with assuring the confidentially of responses.

Data were analyzed using SPSS (Statistical Package for Social Sciences) software, version 20 (IBM, Chicago, Illinois, USA). Number and percentage (\%) of respondents to each IPC measure were calculated in overall sample and then compared between different groups. Comparison was done using Chi-squared $(\chi 2)$ test. A $p$-value of $<0.05$ was considered as statistically significant.

\section{Results:}

The total studied sample was 412 health personnel. Out of them, 316 (77\%) were males, $221(54 \%)$ were of age group $<35$ years of age. While 142 (35\%) of them were physicians, 270 (65\%) were other health-care professionals such as dentists, pharmacists, nurses, and medical ancillary staff. Demographic characteristics of those responded to the survey are shown in Table 1.

\begin{tabular}{|c|c|c|c|}
\hline & Characteristic & Number & Percentage \\
\hline Gender & $\begin{array}{l}\text { Male } \\
\text { Female }\end{array}$ & $\begin{array}{l}316 \\
96\end{array}$ & $\begin{array}{l}77 \% \\
23 \%\end{array}$ \\
\hline Age/years & $\begin{array}{l}<25 \\
25-34 \\
35-44 \\
\geq 45\end{array}$ & $\begin{array}{c}27 \\
194 \\
132 \\
59\end{array}$ & $\begin{array}{l}7 \% \\
47 \% \\
32 \% \\
14 \%\end{array}$ \\
\hline Marital status & $\begin{array}{l}\text { Married } \\
\text { Single } \\
\text { Divorced \Widow }\end{array}$ & $\begin{array}{c}308 \\
99 \\
5\end{array}$ & $\begin{array}{l}75 \% \\
24 \% \\
1 \%\end{array}$ \\
\hline Specialty & $\begin{array}{l}\text { Medicine } \\
\text { Surgery } \\
\text { OBGYN } \\
\text { Pediatric } \\
\text { Radiology / Laboratory } \\
\text { Isolation centers } \\
\text { ER } \\
\text { Other - multiple specialties or administration }\end{array}$ & $\begin{array}{l}39 \\
58 \\
19 \\
31 \\
67 \\
23 \\
39 \\
125\end{array}$ & $\begin{array}{l}9 \% \\
14 \% \\
5 \% \\
8 \% \\
16 \% \\
6 \% \\
9 \% \\
30\end{array}$ \\
\hline Position & $\begin{array}{l}\text { Physician } \\
\text { Nurse or nurse technician } \\
\text { Pharmacist or Pharmacy tech } \\
\text { Dentists } \\
\text { Other healthcare providers (lab techs, radiographers) } \\
\text { Administrative (Drivers, security, others) }\end{array}$ & $\begin{array}{c}142 \\
98 \\
28 \\
7 \\
113 \\
24\end{array}$ & $\begin{array}{l}35 \% \\
24 \% \\
7 \% \\
2 \% \\
27 \% \\
6 \%\end{array}$ \\
\hline Location of work & $\begin{array}{l}\text { Nineveh Health department administration } \\
\text { DOH Hospitals inside Mosul } \\
\text { DOH Hospitals outside Mosul } \\
\text { Primary Health care sectors } \\
\text { Other * }\end{array}$ & $\begin{array}{c}20 \\
235 \\
53 \\
48 \\
51\end{array}$ & $\begin{array}{l}5 \% \\
57 \% \\
13 \% \\
12 \% \\
12\end{array}$ \\
\hline $\begin{array}{l}\text { Source of } \\
\text { information }\end{array}$ & $\begin{array}{l}\text { Health authority instructions } \\
\text { Media } \\
\text { Both }\end{array}$ & $\begin{array}{l}55 \\
54 \\
300\end{array}$ & $\begin{array}{l}13 \% \\
13 \% \\
73 \%\end{array}$ \\
\hline
\end{tabular}

* Mosul University, Humanitarian Organization, or medical detachment at entrances to the city. 
The percentage of staff following different IPC measures was widely ranging from as low as $40 \%$ in wearing a head cover specialized for health personnel, to as high as $97 \%$ in keeping clean hands and trimming fingernails constantly (Table 2). Main defects were found in respiratory hygiene, physical distancing, and self-isolation. Comparison between responses to different IPC measures among males and females is illustrated in Table 2. Females were more likely to sterilize and apply bandages to wounds/scratches as well as trend to wear gloves before examining patients.

Concerning adherence to IPC measures in physicians compared to other health-care staff, this is summarized in Table 3. Physicians were less likely to wash hands from elbows and below for $20 \mathrm{~s}$, put medical and general waste in designated places, wear a protective cover; however, they were more likely to cover mouth and nose completely on cough or sneeze, and wear masks while dealing with patients. On the other hand, physicians were less likely to report deficiency in health protection supplies.

Compared to health-care staff working outside hospitals, those who work in hospitals were better compliant with placing medical and general waste designated areas, as well as sterilizing hands before entering home (Table 4).

Respondents from surgical specialties were found more likely to wash hands from the elbows and below for $20 \mathrm{~s}$, but less likely to cover mouth/nose completely when cough or sneeze as shown in Table 5.

Of note, $332(81 \%)$ of respondents reported benefit from this questionnaire, which was not significantly different between male and female, or those work in hospital and outside hospitals, while more benefit was reported in non-physician respondents compared to physicians.

\section{Discussion}

Health workers are at the front line of the COVID-19 outbreak response, and as such, they are exposed to hazards that put them at risk of infection. Between 10 and 20 percent of United States' coronavirus cases are health-care worker. ${ }^{20}$ Even in Iraq, many COVID-19 cases are being reported daily among health workers, therefore, following proper IPC is very important.

Overall, there are wide ranges of many issues; medical staff is following regarding IPC measures. This can make a sense on how to do proper IPC and how to improve the defective points in future, regarding each entity.

The lowest rate was for wearing head were nearly $2 / 5$ indicating its use. However, this might be explained by the fact that head cover use is not indicated in those who had regular work. Moreover, many health workers do not work in places that have direct contact with COVID-19 patients. Other than

Table 2. Percentage of answers (as strongly agree or somewhat agree) to different questions among all respondents as well as comparison between male and female (total $n=412$ )

\begin{tabular}{|c|c|c|c|c|}
\hline Question & ALL $(n=412)$ & Male $(n=316)$ & $\begin{array}{l}\text { Female } \\
(n=96)\end{array}$ & P value \\
\hline Q1. Keeping at least 1 meter away from others. & $296(72 \%)$ & $230(73 \%)$ & $66(70 \%)$ & 0.471 \\
\hline Q2. Removing ring, keys, watch or metal bracelets while at work. & $291(71 \%)$ & $221(70 \%)$ & $70(74 \%)$ & 0.534 \\
\hline Q3. Keeping clean and trimmed fingernails. & $398(97 \%)$ & $306(98 \%)$ & $92(97 \%)$ & 0.751 \\
\hline Q4. Sterilizing and applying bandages to scratches/wounds. & $327(79 \%)$ & $243(77 \%)$ & $84(88 \%)$ & $0.019 *$ \\
\hline $\begin{array}{l}\text { Q5. Washing hands up to elbows } \times 20 \text { seconds, or use medical } \\
\text { sanitizers before \& after examining patients. }\end{array}$ & $357(87 \%)$ & $276(89 \%)$ & $81(85 \%)$ & 0.362 \\
\hline Q6. Covering mouth and nose on cough or sneeze. & $390(95 \%)$ & $300(96 \%)$ & $90(95 \%)$ & 0.744 \\
\hline Q7. Wearing a mask while dealing with infected patients. & $382(93 \%)$ & $293(94 \%)$ & $89(94 \%)$ & 0.979 \\
\hline Q8. Wearing rubber gloves before examination. & $382(93 \%)$ & $289(92 \%)$ & $93(98 \%)$ & 0.052 \\
\hline Q9. Ensuring to keep hands away from the face. & $372(90 \%)$ & $288(91 \%)$ & $84(88 \%)$ & 0.376 \\
\hline Q10. Disposing medical waste in designated places. & $392(95 \%)$ & $298(95 \%)$ & $94(99 \%)$ & 0.100 \\
\hline $\begin{array}{l}\text { Q11. Wearing a protective cover specialized for health personnel at } \\
\text { work. }\end{array}$ & $273(66 \%)$ & $215(69 \%)$ & $58(62 \%)$ & 0.192 \\
\hline $\begin{array}{l}\text { Q12. Wearing a head cover (for workers in extremely dangerous } \\
\text { areas).** }\end{array}$ & $163(40 \%)$ & $130(58 \%)$ & $33(51 \%)$ & 0.316 \\
\hline $\begin{array}{l}\text { Q13. Cleaning hands or other sterilizing measures before entering } \\
\text { home. }\end{array}$ & $376(91 \%)$ & $288(95 \%)$ & $88(94 \%)$ & 0.774 \\
\hline Other Q1. Did you get benefit from this questionnaire? & $330(80 \%)$ & $255(82 \%)$ & $75(80 \%)$ & 0.672 \\
\hline $\begin{array}{l}\text { Other Q2. Did you suffer from deficiency in health protection supplies } \\
\text { during the outbreak? }\end{array}$ & $321(78 \%)$ & $243(77 \%)$ & $76(81 \%)$ & 0.476 \\
\hline
\end{tabular}

*Statistically significant

**Number of answers in each group is different in this Q: $A L L, n=290$; Male, $n=225$; Female $n=65$. 
Table 3. Comparison of percentage answered as YES (Extremely, or to some extent) to the following Qs between Physicians and all other healthcare staff (total $n=412$ )

\begin{tabular}{|c|c|c|c|}
\hline Question & $\begin{array}{c}\text { Physicians } \\
(n=142)\end{array}$ & $\begin{array}{l}\text { All others } \\
(n=270)\end{array}$ & Pvalue \\
\hline Q1. Keeping at least 1 meter away from others. & $102(\% 71)$ & $196(73 \%)$ & 0.696 \\
\hline Q2. Removing ring, keys, watch or metal bracelets while at work. & $105(73 \%)$ & $186(69 \%)$ & 0.393 \\
\hline Q3. Keeping clean and trimmed fingernails. & $139(\% 99)$ & $260(97 \%)$ & 0.251 \\
\hline Q4. Sterilizing and applying bandages to scratches/wounds. & $108(76 \%)$ & $221(82 \%)$ & 0.141 \\
\hline $\begin{array}{l}\text { Q5. Washing hands up to elbows } \times 20 \text { seconds, or use medical sanitizers before \& } \\
\text { after examining patients. }\end{array}$ & $116(82 \%)$ & $243(91 \%)$ & $0.004^{*}$ \\
\hline Q6. Covering mouth and nose on cough or sneeze. & $140(98 \%)$ & $252(94 \%)$ & 0.075 \\
\hline Q7. Wearing a mask while dealing with infected patients. & $139(97 \%)$ & $245(92 \%)$ & $0.031 *$ \\
\hline Q8. Wearing rubber gloves before examination. & $133(93 \%)$ & $251(94 \%)$ & 0.692 \\
\hline Q9. Ensuring to keep hands away from the face. & $132(92 \%)$ & $241(90 \%)$ & 0.370 \\
\hline Q10. Disposing medical waste in designated places. & $134(94 \%)$ & $260(98 \%)$ & 0.067 \\
\hline Q11. Wearing a protective cover specialized for health personnel at work. & $87(61 \%)$ & $187(70 \%)$ & 0.064 \\
\hline Q12. Wearing a head cover (for workers in extremely dangerous areas).** & $48(45 \%)$ & $119(61 \%)$ & $0.044^{*}$ \\
\hline Q13. Cleaning hands or other sterilizing measures before entering home. & $130(94 \%)$ & $247(95 \%)$ & 0.650 \\
\hline Other Q1. Did you get benefit from this questionnaire? & $106(74 \%)$ & $226(85 \%)$ & $0.006^{*}$ \\
\hline $\begin{array}{l}\text { Other Q2. Did you suffer from deficiency in health protection supplies during the } \\
\text { outbreak? }\end{array}$ & $126(89 \%)$ & $195(73 \%)$ & $<0.001 *$ \\
\hline
\end{tabular}

*Statistically significant

**Number of answers in each group is different in this Q: Doctors, $n=94$; All others, $n=197$

Table 4. Comparison of percentage answered as YES (Extremely, or to some extent) to the following Qs between those working in hospital versus those outside hospitals (total $n=412$ )

\begin{tabular}{lccc}
\hline Question & $\begin{array}{c}\text { Work in } \\
\text { hospital } \\
\text { (n=288) }\end{array}$ & $\begin{array}{c}\text { Work Outside } \\
\text { hospital } \\
\text { (n=124) }\end{array}$ & P value \\
\hline Q1. Keeping at least 1 meter away from others. & $205(71 \%)$ & $93(75 \%)$ & 0.457 \\
Q2. Removing ring, keys, watch or metal bracelets while at work. & $208(72 \%)$ & $83(68 \%)$ & 0.333 \\
Q3. Keeping clean and trimmed fingernails. & $281(98 \%)$ & $118(96 \%)$ & 0.257 \\
Q4. Sterilizing and applying bandages to scratches/wounds. & $226(79 \%)$ & $103(83 \%)$ & 0.315 \\
$\begin{array}{l}\text { Q5. Washing hands up to elbows x 20 seconds, or use medical sanitizers before \& } \\
\text { after examining patients. }\end{array}$ & $248(\% 87)$ & $111(90 \%)$ & 0.531 \\
Q6. Covering mouth and nose on cough or sneeze. & $275(96 \%)$ & $117(94 \%)$ & 0.516 \\
Q7. Wearing a mask while dealing with infected patients. & $271(95 \%)$ & $113(91 \%)$ & 0.166 \\
Q8. Wearing rubber gloves before examination. & $270(94 \%)$ & $114(92 \%)$ & 0.346 \\
Q9. Ensuring to keep hands away from the face. & $261(91 \%)$ & $112(90 \%)$ & 0.923 \\
Q10. Disposing medical waste in designated places. & $279(98 \%)$ & $115(93 \%)$ & $\mathbf{0 . 0 2 1 *}$ \\
Q11. Wearing a protective cover specialized for health personnel at work. & $198(69 \%)$ & $76(63 \%)$ & 0.288 \\
Q12. Wearing a head cover (for workers in extremely dangerous areas). ${ }^{* *}$ & $120(57 \%)$ & $44(55 \%)$ & 0.774 \\
Q13. Cleaning hands or other sterilizing measures before entering home. & $266(96 \%)$ & 111 (90\%) \\
Other Q1. Did you get benefit from this questionnaire? & $236(83 \%)$ & $96(78 \%)$ & $\mathbf{0 . 0 2 2 *}$ \\
$\begin{array}{l}\text { Other Q2. Did you suffer from deficiency in health protection supplies during the } \\
\text { outbreak? }\end{array}$ & $227(79 \%)$ & $94(76 \%)$ & 0.257 \\
\hline
\end{tabular}

*Statistically significant

**Number of answers in each group is different in this Q: Work in hospital, $n=211$; Work Outside hospital, $n=80$. 


\begin{tabular}{|c|c|c|c|}
\hline Question & $\begin{array}{l}\text { Surgical } \\
\text { specialties } \\
(n=77)\end{array}$ & $\begin{array}{l}\text { Medical } \\
\text { specialties } \\
(n=70)\end{array}$ & P value \\
\hline Q1. Keeping at least 1 meter away from others. & $49(64 \%)$ & $52(74 \%)$ & 0.164 \\
\hline Q2. Removing ring, keys, watch or metal bracelets while at work. & $60(78 \%)$ & $48(69 \%)$ & 0.200 \\
\hline Q3. Keeping clean and trimmed fingernails. & $75(98 \%)$ & $66(97 \%)$ & 0.900 \\
\hline Q4. Sterilizing and applying bandages to scratches/wounds. & $62(81 \%)$ & $52(75 \%)$ & 0.452 \\
\hline $\begin{array}{l}\text { Q5. Washing hands up to elbows } \times 20 \text { seconds, or use medical sanitizers before \& } \\
\text { after examining patients. }\end{array}$ & $67(87 \%)$ & $52(75 \%)$ & 0.070 \\
\hline Q6. Covering mouth and nose on cough or sneeze. & 70 (91\%) & $70(100 \%)$ & $0.010^{*}$ \\
\hline Q7. Wearing a mask while dealing with infected patients. & $68(88 \%)$ & $67(96 \%)$ & 0.102 \\
\hline Q8. Wearing rubber gloves before examination. & $69(90 \%)$ & $65(93 \%)$ & 0.489 \\
\hline Q9. Ensuring to keep hands away from the face. & $67(87 \%)$ & $66(94 \%)$ & 0.134 \\
\hline Q10. Disposing medical waste in designated places. & $75(96 \%)$ & $65(93 \%)$ & 0.196 \\
\hline Q11. Wearing a protective cover specialized for health personnel at work. & $49(64 \%)$ & $43(62 \%)$ & 0.869 \\
\hline Q12. Wearing a head cover (for workers in extremely dangerous areas). ${ }^{*}$ & $25(50 \%)$ & $26(52 \%)$ & 0.841 \\
\hline Q13. Cleaning hands or other sterilizing measures before entering home. & $71(96 \%)$ & $61(92 \%)$ & 0.370 \\
\hline Other Q1. Did you get benefit from this questionnaire? & $57(75 \%)$ & $55(79 \%)$ & 0.610 \\
\hline $\begin{array}{l}\text { Other Q2. Did you suffer from deficiency in health protection supplies during the } \\
\text { outbreak? }\end{array}$ & $62(82 \%)$ & $58(83 \%)$ & 0.840 \\
\hline
\end{tabular}

* Statistically significant.

**Number of answers in each group is different in this Q: Surgical specialties, $n=50$; Surgical specialties, $n=50$.

this, nearly $70 \%$ of the sample does not remove their rings and watches while performing hand washing. In addition, a similar percentage does not follow social distancing and keeping $1 \mathrm{~m}$ or more distance than other people or patient. This might be a core step in IPC but not well-known by the medical staff due to poor IPC training courses or may be due to increasing number of patients in very small health facilities.

No significant difference was identified between male female practices, except for sterilizing and applying bandages to scratches/wounds, where females are more adhere compared to male. There is a similar finding from another study done in USA. ${ }^{21}$

With regards to physicians compared to other medical staff, physicians are less adherent to hand sanitations, wearing head cover while they are in their shift, but they are more careful about wearing facemasks during their shifts than others. This equipment was recommended by US Food and Drug Administration society as personal protective measures. ${ }^{22}$ Compared to medical staff who work outside the hospital, those who work inside the hospital are more adherent about throwing medical waste in their special places, and they are more careful to avoid spreading the infection to their houses than those who are working outside the hospital. This may due to more serious types of infections and invasive techniques faced by medical staff working inside the hospital. ${ }^{23}$

At another comparison, surgical staff is more careful for hand sanitation but they are less serious in covering their mouth during coughing and sneezing. This finding might be due to the special work environment facing each specialty. Most germs spread airborne which means that while sneezing or coughing millions of germs into the air are sending and other people might breathe them in and get infected. ${ }^{24}$

In general, $22 \%$ of respondents indicated shortage in personal protective equipment (PPE). PPE shortages had been recognized in many areas of the world with COVID-19 pandemic; however data collection was just at beginning of the pandemic in Nineveh and few cases had been registered by that time.

This study has a number of limitation and challenges. Firstly, there are no national data existing on the IPC control for Iraqi medical staff related to COVID-19 or other infectious diseases, for comparison. Additionally, due to the shortage of time and the situation related to COVID-19 lockdown, we could collect 412 respondents, which represent major part of the medical staff but not all of them.

\section{Conclusion}

IPC is a crucial element when medical staff handles or treat any infectious disease. Hand washing, respiratory hygiene, physical distancing, and self-isolation were the main issues to control infection.

Staff from all medical specialties had some defects in one of the areas relevant to adherence to infection prevention and control. This might be due to lack of medical educational materials, poor working environment, or lack of seriousness when dealing with infectious diseases in general, or the current pandemic in specific. So, training on how to do proper IPC is important for all of them. Regardless of COVID-19 pandemic, the study was done in order to improve the concept of infection control. 
As this study provided assessment of the situation and adherence to IPC measures in Nineveh governorate, it can build a basic stone for conducting further studies in future and collaborate with other cities to compare the medical staff attitude as well as follow-up after education or other measures to improve this poor adherence.

The medical staff still needs more governmental support for protective measures; however, there are certain measures that all staff can take on their own to protect themselves as well as others whom they encounter. In addition, we urge non-governmental organizations to improve currently available services and provide more protective supplies as much as possible.

\section{Conflicts of Interest Disclosure}

All authors indicate that there is no actual or potential conflicts of interest with regard to this manuscript.

\section{References:}

1. World Health Organization, "Coronavirus disease 2019". URL available at: https://www.who.int/emergencies/diseases/novel-coronavirus 2019?gclid =Cj0KCQjwoub3BRC6ARIsABGhnyZD1crD-ZuEuTqBtpir7_9utKEepmAq0NVz uyyWtQz6tQVNpcjcogEaAluCEALw wcB.

2. World Health Organization, "WHO Director-General's opening remarks at the media briefing on COVID-19 - 11 March 2020". URL available at: https:// www.who.int/dg/speeches/detail/who-director-general-s-openingremarks-at-the-media-briefing-on-covid-19---11-march 2020

3. Worldometer, "COVID-19 coronavirus pandemic". Accessed on 3 July 2020 Available at: https://www.worldometers.info/coronavirus/country/iraq.

4. Medecins Sans frontiers, "A year on from battle, Mosul's healthcare system is still in ruins" 9 July 2018. Accessed on 11 May 2020. URL available at: https:// www.msf.org/year-battle-mosul\%E2\%80\%99s-healthcare-system-still-ruins

5. UNICEF, "Fighting COVID-19 deepens Iraq's humanitarian crisis" 21 April 2020. Accessed on 11 May 2020. URL available at: https://blogs.unicef.org/ blog/fighting-covid-19-deepens-iraqs-humanitarian-crisis/

6. Center for disease control and prevention, "Guidelines for environmental infection control in health-care facilities" 2003 updated: July 2019. Assessed at 11 May. Available at: http://www.faqs.org/health/topics/74/Infectioncontrol.html.

7. Medicine for Humanity, "COVID-19 global pandemic". URL available at: https://medicinesforhumanity.org/wp-content/uploads/2020/04/COVID19-Curriculum_MFH-final version_4.14.20.pdf

8. Liu J, Liao X, Qian S, Yuan J, Wang F, Liu Y, et al. Community transmission of severe acute respiratory syndrome Coronavirus 2, Shenzhen, China, 2020. Emerg Infect Dis. 2020 Jun 17;26(6).

9. Chan JF, Yuan S, Kok KH, To KK, Chu H, Yang J, et al. A familial cluster of pneumonia associated with the 2019 novel coronavirus indicating person- to-person transmission: A study of a family cluster. The Lancet. 2020 Feb 15:395(10223):514-23

10. Li Q, Guan X, Wu P, Wang X, Zhou L, Tong Y, et al. Early transmission dynamics in Wuhan, China, of novel coronavirus-infected pneumonia. N Engl J Med. 2020 Jan 29.

11. Huang C, Wang Y, Li X, Ren L, Zhao J, Hu Y, et al. Clinical features of patients infected with 2019 novel coronavirus in Wuhan, China. The Lancet. 2020 Feb 15;395(10223):497-506.

12. Burke RM, Midgley CM, Dratch A, Fenstersheib M, Haupt T, Holshue M, et al. Active monitoring of persons exposed to patients with confirmed COVID19-United States, January-February 2020. MMWR. Morbid Mortal Weekly Rep. 2020 Mar 6;69(9):245-6.

13. World Health Organization. Report of the "WHO-China Joint Mission on Coronavirus Disease 2019 (COVID-19)"16-24 February 2020. URL available at: https://www.who.int/docs/default-source/coronaviruse/who-chinajoint-mission-on-covid-19-final-report.pdf

14. Center for Disease Control and Prevention, "Coronavirus Disease 2019-Using PPE" Last accessed on June 9, 2020. URL available at: https://www.cdc.gov/ coronavirus/2019-ncov/hcp/using-ppe.html

15. Center for Disease Control and Prevention, "Prevention \& Treatment". 15 February 2020. Archived from the original on 15 December 2019. URL available at: https://www.cdc.gov/coronavirus/mers/about/prevention. html.

16. World Health Organization, "Coronavirus disease (COVID-19) advice for the public". URL available at: www.who.int/emergency/diseases/novelcoronavirus-2019/advice-for-public

17. Adigun A, Johnson J. Physical distancing, masks can dramatically reduce COVID-19 transmission. AbcNEWS. URL available at: https://abcnews. go.com/Health/optimal-physical-distancing-facial-protection-reducecovid-19/story?id=71019436.

18. Hersh E, Goodwin M. How long is the incubation period for the Coronavirus?. Healthline. March 13, 2020 URL available at: https://www. healthline.com/health/coronavirus-incubation-period.

19. World Health Organization, "Coronavirus disease (COVID-19) advice for public". URL available at: https://www.who.int/emergencies/diseases/novelcoronavirus-2019/advice-for-public.

20. Nicholson L." Thousands of health care workers infected with coronavirus, CDC report finds". Reuters News. April 15, 2020. URL available at: https:// www.nbcnews.com/health/health-news/thousands-health-care-workersinfected-coronavirus-cdc-report-finds-n1183886.

21. Hamblin J. "Evidence of the superiority of female doctors"The Atlantic Health. December 2016. URL available at: https://www.theatlantic.com/ health/archive/2016/12/female-doctorssuperiority/511034/.

22. US Food and drug Administration "Isolation gown" last update 11-3-2020. URL available at: https://www.fda.gov/medical-devices/general-hospitaldevices-and-supplies/personal-protective-equipment-infection-control.

23. Better Health Channel, "Preventing healthcare associated infection". Feb 2019. URL available at: https://www.betterhealth.vic.gov.au/health/ conditionsandtreatments/infections-in-hospital-reduce-the-risk.

24. Center for Disease Control and Prevention, "Water, sanitation and environmentally-related hygiene- coughing and sneezing" updated on April 22, 2020. URL available at: https://www.cdc.gov/healthywaterlhygiene/ etiquettelcoughing_sneezing.html.

This work is licensed under a Creative Commons Attribution-NonCommercial 3.0 Unported License which allows users to read, copy, distribute and make derivative works for non-commercial purposes from the material, as long as the author of the original work is cited properly. 